\title{
小児外傷性脳内血腫の臨床的特徵
}

\author{
松元 幹郎・ 三瓶 建二·西川 秀人・関 忠和・柴田 家門・寺尾 栄夫
}

\section{Characteristics of Traumatic Intracerebral Hematomas in Children}

\author{
Mikiro Matsumoto, Kenji SanPei, Hideto Nishikawa, Tadakazu SeKi, \\ Iekado SHIBATA and Hideo Terao \\ Department of Neurosurgery, Toho University, Tokyo
}

\begin{abstract}
The authors retrospectively compared various features of traumatic intracerebral hematoma (TICH) in 15 children and 25 adults. The patients were divided into two groups according to the hematoma site, i.e., cortical/subcortical and central, and their clinical courses, neurological findings and, in particular, computed tomography (CT) scans were analyzed.

Most of hematomas in the cortical/subcortical group developed as a result of cerebral contusion. The majority of children in this group were males and trauma was mainly incurred in traffic accidents. On the other hand, falls as well as traffic accidents were the primary causes of TICH in the adults. Most cortical/subcortical hematomas developed soon after head injury, although some evolved gradually in an area that had appeared isodense on the initial CT scan. Completion of this type of hematoma took longer in children than in adults. In pediatric patients, TICHs often were located in the occipital and parietal lobes, whereas most of the adult TICHs developed in the frontal and anterior temporal lobes. TICHs and their causative contusions were generally smaller in the pediatric population and less frequently required surgery, the operative rates being $22.2 \%$ among children and $85.7 \%$ among adults. In children, the outcome of cortical/subcortical TICH was favorable.

Small hematomas in the corpus callosum, basal ganglia, and paraventricular region were included in the central hematoma group. These hematomas were believed to have developed through shearing strain. The incidence of central hematoma was significantly higher in children than in adults, and the adults in this group tended to be young. The outcome in children was somewhat better than that in adults.
\end{abstract}

Key words: traumatic intracerebral hematoma, cerebral contusion, shearing strain

\section{I はじめに}

急性頭部外傷のなかで，治療面における重要な疾患の一 つである外慯性脳内血腫については多くの報告がなされて いる。しかし，そのほとんどは成人についてであり，小児 の外傷性脳内血腫に関したまとまった報告, 特にCT 所見 と関連させたものは予想外に少なく，その病態の解明は十
分にはなされていない。

我々は，小児外傷性脳内血腫は成人とは異なった臨床的 特徵を有するものと考元，CT 所見を中心にその特徽を検 討したので報告する。

\section{III対象および方法}

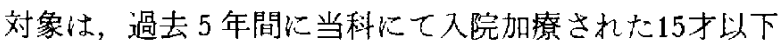

東邦大学脳神経外科

Address reprint requests to: M. Matsumoto, M.D., Department of Neurosurgery, Toho University, 6-11-1 Ohmori-nishi, Ohta-ku, Tokyo 143.

受稿 1987 年 3 月18日 受理 1988 年 2 月 15 日 
の分娩外傷を除〉頭部外傷患者のうち，CT 所見より外傷 性脳内血腫と診断された 15 例である。 また，過去 3 年間に 入院加療された16才以上の外傷性脳内血腫患者25例を対照 群として比較検討した。これるで外傷性脳内血腫の CT 上 の定義および分類に一定のものはない，本報告で， CT 上に乱计る実測 $1 \mathrm{~cm}$ 以上の high density を血腫とし，血 腫の部位によって皮質・皮質下血腫群と中心白質部血腫群 に大別した。 また，血腫の大きさを $1 \sim 3 \mathrm{~cm}, 3 \sim 5 \mathrm{~cm}, 5$ $\mathrm{cm}$ 以上の 3 群に分け，おの扰のを small, medium, large と表現した。院時の意識状態は Glasgow Coma Scale (GCS) ${ }^{11)}$ ，転帰は Glasgow Outcome Scale (GOS) ${ }^{22)}$ で表し た、CTは啇宜臨床症状に俯じて行ったが，結果的に急性 期には全例で毎日または1日ごとに行われた。なお，用い た機種はEMI 1010, slice厚は $1.0 \mathrm{~cm}$, slice 面は OM line に平行とした。

\section{III 結 果}

\section{1. 皮質・皮梊下血腫群}

皮質および皮質下に血腫を認めた群であり，さらに血腫
の出現形式に上り以下の 3 群に分類した。

I 群(Table 1，Fig. 1)：受傷より初回 CT むでの時間に 関係なく，初回 CTですでに血腫を認めた群で，小児 5 例 $(33 \%)$ が本群に属し，男児 3 例，女児 2 例，年齢は1 15 才(平均 8 才)であった。受傷機転は交通外傷 1 例, 転倒ま た踥転落 4 例で，全例に骨折を認めた。血腫と外力との関 倸は coup injury 3 例, contre-coup injury 2 例であった。

入院時 GCS は 6 15(平均10.2)，受傷より初回 CT で の時間法 2 時間 3 例， $3 \sim 5$ 時間 2 例であった，前頭葉の 1 例と側頭葉の 1 例では成人と同様に血腫も大きく挫傷む 強かったが，他の3 例は外力直線上の頭頂葉にみられ，血 腫も小さく挫傷も軽殿であり,さらに 2 回日以降の CTで も血腫の増大は認められなかった。1例のみに手術が行え れ，転㷌は軽快退院 3 例，片麻痺 1 例，死亡 1 例であっ t.

刘照群として成人 11 例 $(44 \%)$ が本群に相当し，男性 10 例，女性 1 例，年路は33〜75才(平均55.8才)であった。受 傷機転は交通外傷 2 例, 転倒または転落 9 例で, 5 例に骨 折を認內, 血腫と外力の関保は coup injury 3 例, contre-

Table 1 Patients with intracerebral hematomas detected on initial computed tomography (CT) scans

\begin{tabular}{|c|c|c|c|c|c|c|c|c|c|}
\hline $\begin{array}{l}\text { Case } \\
\text { No. }\end{array}$ & $\begin{array}{l}\text { Age, } \\
\text { Sex }\end{array}$ & Gause & Fracture & Impact & $\begin{array}{c}\text { GCS score } \\
\text { on } \\
\text { admission }\end{array}$ & $\begin{array}{l}\text { Interval } \\
\text { from trauma } \\
\text { to initial CT }\end{array}$ & $\begin{array}{c}\text { Size of } \\
\text { hematoma }\end{array}$ & Surgery & $\begin{array}{l}\text { GOS } \\
\text { score }\end{array}$ \\
\hline 1 & $1, \mathrm{M}$ & fall & + & coup & 6 & 2 hours & small & - & $\mathrm{MD}$ \\
\hline 2 & $6, \mathrm{M}$ & fall & + & coup & 13 & 2 hours & medium & - & GR \\
\hline 3 & $15, \mathrm{M}$ & fall & + & $\begin{array}{l}\text { contre- } \\
\text { coup }\end{array}$ & 7 & 2 hours & large & + & $\mathrm{D}$ \\
\hline 4 & $7, \mathrm{~F}$ & $\begin{array}{l}\text { traffic } \\
\quad \text { accident }\end{array}$ & + & $\begin{array}{l}\text { contre- } \\
\text { coup }\end{array}$ & 10 & 3 hours & small & - & GR \\
\hline 5 & $11, \mathrm{~F}$ & fall & + & coup & 15 & 5 hours & small & - & GR \\
\hline 1 & $71, \mathrm{M}$ & fall & - & $?$ & 8 & 3 hours & large & + & $\mathrm{V}$ \\
\hline 2 & $75, \mathrm{M}$ & $\begin{array}{l}\text { traffic } \\
\text { accident }\end{array}$ & + & coup & 13 & 24 hours & large & + & $\mathrm{V}$ \\
\hline 3 & $33, \mathrm{M}$ & fall & + & $\begin{array}{l}\text { contre- } \\
\text { coup }\end{array}$ & 15 & 20 hours & medium & - & GR \\
\hline 4 & $58, \mathrm{~F}$ & $\begin{array}{l}\text { traffic } \\
\quad \text { accident }\end{array}$ & - & $?$ & 10 & 9 hours & medium & - & $\mathrm{D}$ \\
\hline 5 & $68, \mathrm{M}$ & fall & - & $\begin{array}{l}\text { contre- } \\
\text { coup }\end{array}$ & 8 & 3 hours & large & + & $\mathrm{D}$ \\
\hline 6 & $41, \mathrm{M}$ & fall & + & coup & 15 & 3 hours & medium & + & GR \\
\hline 7 & $56, \mathrm{M}$ & fall & - & $\begin{array}{l}\text { contre- } \\
\text { coup }\end{array}$ & 12 & 10 hours & large & + & GR \\
\hline 8 & $51, \mathrm{M}$ & fall & - & $?$ & 13 & 10 days & medium & + & GR \\
\hline 9 & $62, \mathrm{M}$ & fall & - & $\begin{array}{l}\text { contre- } \\
\text { coup }\end{array}$ & 10 & 2 hours & large & + & GR \\
\hline 10 & $48, \mathrm{M}$ & fall & + & $\begin{array}{l}\text { contre- } \\
\text { coup }\end{array}$ & 8 & 4 hours & large & + & $\mathrm{D}$ \\
\hline 11 & $\bar{\jmath} 1, M$ & fall & + & coup & 15 & 2 hours & medium & + & GR \\
\hline
\end{tabular}

${ }^{*}$ Small: 1 to $3 \mathrm{~cm}$, medium: 3 to $5 \mathrm{~cm}$, large: over $5 \mathrm{~cm}$ in maximum diameter. GCS indicates Glasgow Coma Scale; GOS, Glasgow Outcome Scale; GR, good recovery; $\mathrm{MD}$, moderate disability; SD, severe disability; V, persistent vegetative state; $\mathrm{D}$, death. 

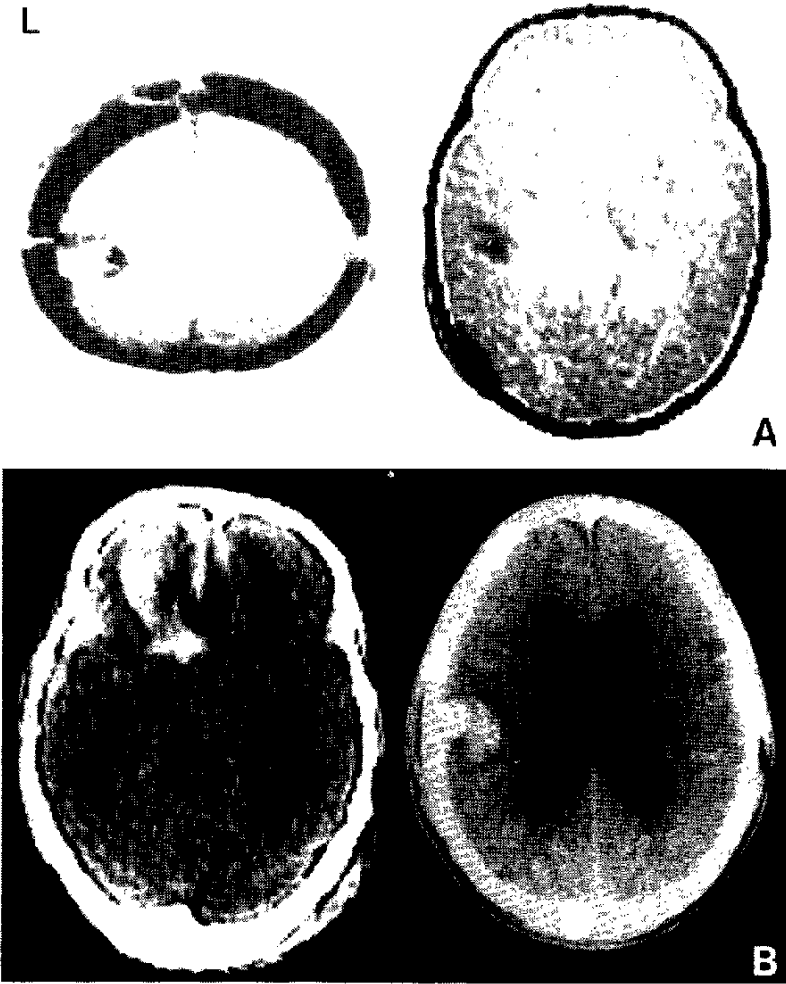

Fig. 1 Representative computed tomography (GT) scans of Group I. A: Small intracerebral hematomas in two pediatric cases. B: Large contusional hematoma (left) and so-called primary hematoma $\langle$ right $\rangle$ in two adults.

coup injury 5 例，不明 3 例であった。入院時 GCS は 8〜 15(平均11.5)，受傷上り初回 CT までの時間は 3 時間から 10 日で，4時間以内 6 例，9 10時間 2 例， $20 \sim 24$ 時間 2 例，10日 1 例であった．血腫は全例で比較的大きく，9例 は強い挫傷を伴った血腫が前頭葉または側頭葉にあり、一 方 2 例は挫傷も強くなく比較的境界明瞭な円形の血腫が外 力直線上の頭頂葉にみられた，右前頭葉内血腫で症状もな く保存的に加療された 1 例, および入院後急速に症状が悪 化し手術までに至らなかった1例を除き，9例でただちに 手術が行われ, 転㷌は軽快退院 6 例, 植物状態 2 例, 死亡 3 例であった。

II 群(Table 2, Fig. 2)：初回 CT 上の挫傷部位に以後の CTで血腫の形成をみた群であり，小児例は8才男児の 1 例 $(6.7 \%)$ で，交通外傷による受傷で骨折を認め，外力と の関倸は coup injury であり，入院時の GCS は 8であ。 た。受傷後 2 時間目のCTで左小脳半球に小さな挫傷を認 め，48時間後の CT で中等大の血腫形成を認めたため手術 を行い，軽度の小脳症状残して退院した。

対照群は 8 例(32\%)で全例男性であり，年秢は $31 〜 80$ 才
(平均55.6才)，受傷機転は交通外傷 5 例，転倒または転落 3 例で, 7 例に骨折を認めた。血腫と外力之の関係は coup injury 4 例，contre-coup injury 4 例であった，入院時 の GCS は 7 15(平均 10.1), 受傷上り初回 CT までの時 間は全例 3 時間以内で, 初回 CTより血腫出現をでの時間 は24時間が 4 例，48時間が 2 例，72時間が 2 例であった。 血腫は全例で比較的大きく前頭葉または側頭葉にあり，7 例に手術が行われた。転帰は軽快退院 1 例, 失見当識 1

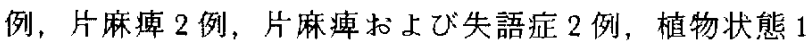
例，死亡 1 例であった。

III群（Table 3，Fig. 3)：初回 CT 上異常のなかった部位 に以後の CT T゙血腫の形成をみた群であり，小児は 3 例 （20\%）で全例男児であった。年齢は11才，5才，3才，受傷 機転はいずれる交通外傷で 2 例に骨折を認め，血腫と外力 之の関倸は 2 例が contre-coup injury で 1 例は不明であっ た. 入院時の GCS は 8,12,7(平均 9), 受傷上り初回 CT までの時間はすべて 3 時間以内で，初回 CTより血尰形成 まではそれぞれ 3 日，4 日，5 日で，血腫は前頭葉 2 例， 後頭葉 1 例にみられ大きさも比較的小さく，挫傷も認めら れなかった。手術は 1 例子行わ机す，転㷌恃軽快退院 1 例，性格変化 1 例，片麻疸 1 例であった。

成人対照群は 2 例 $(8 \%)$ でいず扎男性，年秢は 58 才， 47 才，受傷機転は之もに転落であり，1例に骨折を諗め た. 血腫と外力との関係は, いずれも contre-coup injury であった。入院時の GCS は13および8，受傷上り初回 CT での時間はいずれる 2 時間，初回 CT より血腫形成 までの時間は 2 例とも24時間で，1例では硬膜下血腫除去 と外減圧術後に血腫の形成るみた，血腫はいずれも大きく 前頭葉あるいは側頭葉中心にみられ，強い挫傷を伴ってい た、いずれるただらに手術が行われ，それぞれ片麻疸と失 語症, 記銘力障害を残して退院した。

\section{2. 中心白質部血腫群}

脳梁，基底核，傍側脳室に血腫を認め大群を中心白質部 血腫群とした(Table 4，Fig. 4)。本群の小児は6 例(40\%) で全例男児，年齢は 2 15才(平均6.7才)，受傷機転は全 例交通外傷で骨折は 1 例にも認められず，杰た血腫と外力 との関倸は全例不明であった，入院時の GCS は 5 9(平 均6.7）と，高度の意識障害を示していた，受傷上り初回 CT での時間は全例 3 時間以内であり, 血腫の部位は脳 梁 1 例, 脳梁扣よび基底核 2 例，基底核 1 例，傍側脳室 2 例であり，基底核部血腫の 1 例のみに手術が行われた。転 㷌は軽快退院 2 例, 片麻㾝 2 例, 性格变化と片麻瘻 1 例, 失語症と片麻㽽 1 例であった，

対照群は 4 例 $(16 \%)$ で全例男性，年齢は19〜28才(平均 21.5 才)，受傷機転は全例が交通外傷で，2例に骨折を認 
Table 2 Patients with cerebral contusions detected on initial CT scans, with subsequent development of intracerebral hematomas

\begin{tabular}{|c|c|c|c|c|c|c|c|c|c|c|c|}
\hline $\begin{array}{l}\text { Case } \\
\text { No. }\end{array}$ & $\begin{array}{l}\text { Age, } \\
\text { Sex }\end{array}$ & Gause & Fracture & Impact & $\begin{array}{c}\text { GCS score } \\
\text { on } \\
\text { admission }\end{array}$ & $\begin{array}{l}\text { Interval } \\
\text { from trauma } \\
\text { to initial } \mathrm{CT}\end{array}$ & $\begin{array}{l}\text { Initial } \\
\text { GT } \\
\text { findings }\end{array}$ & $\begin{array}{l}\text { Interval between } \\
\text { initial CT and } \\
\mathrm{CT} \text { showing } \\
\text { hematoma }\end{array}$ & $\begin{array}{c}\text { Size of } \\
\text { hematoma }\end{array}$ & Surgery & $\begin{array}{l}\text { GOS } \\
\text { score }\end{array}$ \\
\hline 1 & $8, \mathrm{M}$ & $\begin{array}{l}\text { traffic } \\
\text { accident }\end{array}$ & + & coup & 8 & 2 hours & contusion & 48 hours & medium & + & $\mathrm{MD}$ \\
\hline 1 & $51, \mathrm{M}$ & $\begin{array}{l}\text { traffic } \\
\quad \text { accident }\end{array}$ & + & coup & 9 & 3 hours & $\begin{array}{l}\text { contusion, } \\
\text { SAH }\end{array}$ & 24 hours & medium & + & $\mathrm{V}$ \\
\hline 2 & $39, \mathrm{M}$ & $\begin{array}{l}\text { traffic } \\
\quad \text { accident }\end{array}$ & + & $\begin{array}{r}\text { contre- } \\
\text { coup }\end{array}$ & 7 & 2 hours & $\begin{array}{l}\text { contusion, } \\
\text { EDH }\end{array}$ & 24 hours & large & + & $\mathrm{SD}$ \\
\hline 3 & $50, \mathrm{M}$ & $\begin{array}{l}\text { traffic } \\
\text { accident }\end{array}$ & - & $\begin{array}{r}\text { contre- } \\
\text { coup }\end{array}$ & 11 & 2 hours & contusion & 24 hours & medium & - & GR \\
\hline 4 & $70, \mathrm{M}$ & $\begin{array}{l}\text { traffic } \\
\quad \text { accident }\end{array}$ & + & coup & 15 & 2 hours & contusion & 72 hours & large & + & $\mathrm{MD}$ \\
\hline 5 & $31, \mathrm{M}$ & $\begin{array}{l}\text { traffic } \\
\text { accident }\end{array}$ & + & coup & 7 & 2 hours & contusion & 48 hours & medium & + & $\mathrm{D}$ \\
\hline 6 & $80, \mathrm{M}$ & fall & + & $\begin{array}{r}\text { contre- } \\
\text { coup }\end{array}$ & 12 & 2 hours & contusion & 72 hours & large & + & MD \\
\hline 7 & $61, \mathrm{M}$ & fall & + & $\begin{array}{r}\text { contre- } \\
\text { coup }\end{array}$ & 8 & 2 hours & contusion & 24 hours & medium & + & SD \\
\hline 8 & $63, \mathrm{M}$ & fall & + & coup & 12 & 2 hours & contusion & 48 hours & medium & + & MD \\
\hline
\end{tabular}

SAH indicates subarachnoid hemorrhage; EDH, epidural hematoma. For other abbreviations, see Table 1.
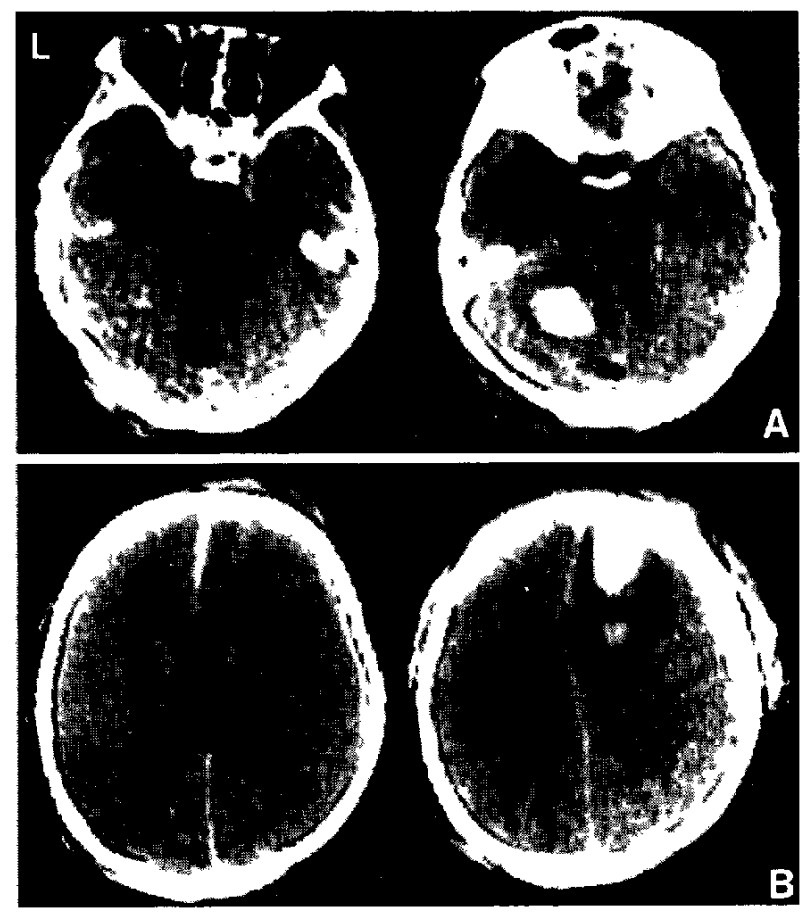

Fig. 2 Representative sequential CT scans of Group II. Initial CT scans (left) showed small contusions (arrow), which progressed to intracerebral hematomas, seen on repeat CT scans (right). A: Child, B: adult. The low-density area in the child's cerebellum was thought to be an arachnoid cyst.
めた。血腫と外力との関係は coup injury が 2 例で, 残る 2 例は不明で市った。入院時の GCS は 6〜14(平均8.5) と 意識障害が強かった。受傷より初回 CT までの時間は全例 2 時間で，血腫は脳梁 2 例，基底核 2 例に認められた，手 術は 1 例子行われず, 転㷌は軽快退院, 片麻軒, 植物状 態, 死亡各 1 例であった。

\section{$N$ 考察}

CT の導入以降，外傷性脳内血腫の診断はきわめて容易 となり，さらにその病態执よで血腫形成機序に関しても考 察され，それらに基つきいくつかの分類も試みられてい る3,4,8,17,24)がをだ一定のものはない，今回我及は，小児の 外傷性脳内血腫の臨床的特徵の検討を試久たが，血腫の部 位の夕でなく血腫形成機序も異なるものとして，対象症例 を皮質・皮質下㳑腫群と中心白質部血腫群の 2 群に分類し て検討した。

\section{1. 皮翼・皮質下血腫群}

外傷性脳内血腫の多くは本群に属し，その血腫の形成機 序は次の 2 つ要䄪される. 第 1 の機序は外傷による血管 損傷によって一次的に血腫の形成をみるものであり4,17,24), 第 2 の機序は外傷によってまず挫傷部に小出血斑が形成ざ れ，ついで Scheinker㧍よび Evansの vasoparalysisの理 論6,7,21)で説明される代謝の変化によって時間の経過とと もに小出血斑が融合㹡大して血腫が形成されるとするるの で，血腫形成機序の基盤をすべて脳挫傷に求めるものであ 
Table 3 Patients with isodense areas on initial CT scans where intracerebral hematomas were detected on repeat scans

\begin{tabular}{|c|c|c|c|c|c|c|c|c|c|c|}
\hline $\begin{array}{l}\text { Case } \\
\text { No. }\end{array}$ & $\begin{array}{l}\text { Age, } \\
\text { Sex }\end{array}$ & Cause & Fracture & Impact & $\begin{array}{l}\text { GCS score } \\
\text { on } \\
\text { admission }\end{array}$ & $\begin{array}{l}\text { Interval } \\
\text { from trauma } \\
\text { to initial CT }\end{array}$ & $\begin{array}{c}\text { Interval between } \\
\text { initial CT and } \\
\mathrm{CT} \text { showing } \\
\text { hematoma }\end{array}$ & $\begin{array}{c}\text { Size of } \\
\text { hematoma }\end{array}$ & Surgery & $\begin{array}{l}\text { GOS } \\
\text { score }\end{array}$ \\
\hline 1 & $11, \mathrm{M}$ & $\begin{array}{l}\text { traffic } \\
\text { accident }\end{array}$ & + & $\begin{array}{r}\text { contre- } \\
\text { coup }\end{array}$ & 8 & 2 hours & 3 days & small & - & GR \\
\hline 2 & $5, \mathrm{M}$ & $\begin{array}{l}\text { traffic } \\
\quad \text { accident }\end{array}$ & + & $\begin{array}{r}\text { contre- } \\
\text { coup }\end{array}$ & 12 & 2 hours & 4 days & small & - & MD \\
\hline 3 & $3, \mathrm{M}$ & $\begin{array}{l}\text { traffic } \\
\text { accident }\end{array}$ & - & $?$ & 7 & 3 hours & 5 days & medium & - & MD \\
\hline 1 & $58, \mathrm{M}$ & fall & + & $\begin{array}{r}\text { contre- } \\
\text { coup }\end{array}$ & 13 & 2 hours & 24 hours & large & + & $\mathrm{MD}$ \\
\hline 2 & $47, \mathrm{M}$ & fall & - & $\begin{array}{r}\text { contre- } \\
\text { coup }\end{array}$ & 8 & 2 hours & 24 hours & large & + & $\mathrm{SD}$ \\
\hline
\end{tabular}
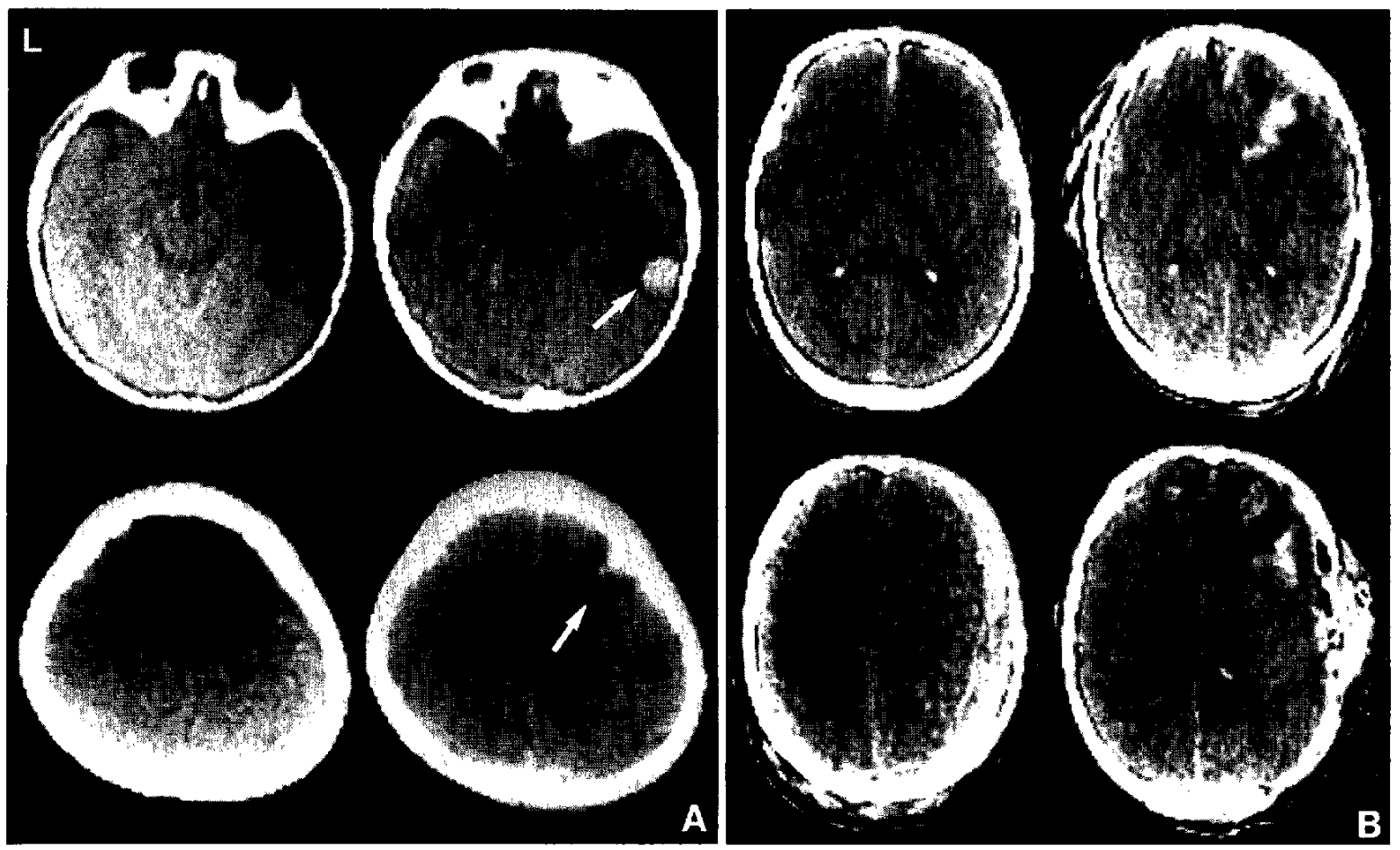

Fig. 3 Sequential CT scans of Group III. A: Initial CT scans of two children (left) showed no abnormalities, whereas repeat scans obtained 3 (upper right) and 4 days later (lower right) revealed intracerebral hematomas (arrow). B: Initial CT scans of adults showed no intracerebral hematoma. However, in one case, a large subdural hematoma was observed (lower left). Evacuation and external decompression were performed a few hours after admission. Repeat CT scans obtained 24 hours after the initial CT scans revealed contusional hematomas (righi).

る2,3,9,17)，最近多くの議論を呼んでいる，いわわる遅発性

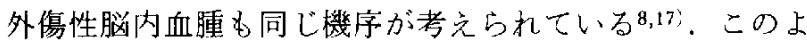
うな血腫形成機序の観点よりみると，我々の症例のうちI 群中 2 例はその血腫の形態より第1の機序が考克られる が，他のすべての症例は第 2 の機序により血腫が形成され
たと考兄られる、すなわち，初回 CTが isodensityであっ た而群においても， isodensity 子脳挫傷のCT 所見の一つ

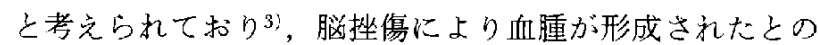
考完も妥当であるう，以上のことより，I群は血腫形成の 時相を，II・III群は脳挫傷より血腫形成をでの経過を観察 
Table 4 Patients with central hematomas

\begin{tabular}{|c|c|c|c|c|c|c|c|c|c|c|}
\hline $\begin{array}{l}\text { Gase } \\
\text { No. }\end{array}$ & $\begin{array}{l}\text { Age, } \\
\text { Sex }\end{array}$ & Cause & Fracture & Impact & $\begin{array}{l}\text { GCS score } \\
\text { on } \\
\text { admission }\end{array}$ & $\begin{array}{c}\text { Interval } \\
\text { from trauma } \\
\text { to initial CT }\end{array}$ & $\begin{array}{l}\text { Location of } \\
\text { hematoma }\end{array}$ & $\begin{array}{c}\text { Size of } \\
\text { hematoma }\end{array}$ & Surgery & $\begin{array}{l}\text { GOS } \\
\text { score }\end{array}$ \\
\hline 1 & $6, \mathrm{M}$ & $\begin{array}{l}\text { traffic } \\
\quad \text { accident }\end{array}$ & - & $?$ & 6 & 3 hours & paraventricle & small & - & GR \\
\hline 2 & $2, \mathbf{M}$ & $\begin{array}{l}\text { traffic } \\
\quad \text { accident }\end{array}$ & - & $?$ & 6 & 2 hours & corpus callosum & small & - & MD \\
\hline 3 & $15, \mathbf{M}$ & $\begin{array}{l}\text { traffic } \\
\quad \text { accident }\end{array}$ & - & $?$ & 9 & 2 hours & $\begin{array}{l}\text { basal ganglia, } \\
\text { corpus callosum }\end{array}$ & small & - & GR \\
\hline 4 & $3, \mathrm{M}$ & $\begin{array}{l}\text { traffic } \\
\text { accident }\end{array}$ & - & $?$ & 7 & 3 hours & paraventricle & small & - & $\mathrm{MD}$ \\
\hline 5 & $3, \mathrm{M}$ & $\begin{array}{l}\text { traffic } \\
\quad \text { accident }\end{array}$ & - & $?$ & 7 & 3 hours & $\begin{array}{l}\text { basal ganglia, } \\
\text { corpus callosum }\end{array}$ & small & - & $\mathrm{MD}$ \\
\hline 6 & $11, \mathrm{M}$ & $\begin{array}{l}\text { traffic } \\
\text { accident }\end{array}$ & - & $?$ & 5 & 3 hours & basal ganglia & medium & + & $\mathrm{SD}$ \\
\hline 1 & $19, \mathrm{M}$ & $\begin{array}{l}\text { traffic } \\
\text { accident }\end{array}$ & - & $?$ & 14 & 2 hours & corpus callosum & small & - & GR \\
\hline 2 & $19, \mathrm{M}$ & $\begin{array}{l}\text { traffic } \\
\quad \text { accident }\end{array}$ & - & $?$ & 8 & 2 hours & basal ganglia & medium & - & SD \\
\hline 3 & $20, \mathrm{M}$ & $\begin{array}{l}\text { traffic } \\
\quad \text { accident }\end{array}$ & + & coup & 6 & 2 hours & corpus callosum & medium & - & $\mathrm{D}$ \\
\hline 4 & $28, \mathrm{M}$ & $\begin{array}{l}\text { traffic } \\
\quad \text { accident }\end{array}$ & + & coup & 6 & 2 hours & basal ganglia & small & - & V \\
\hline
\end{tabular}
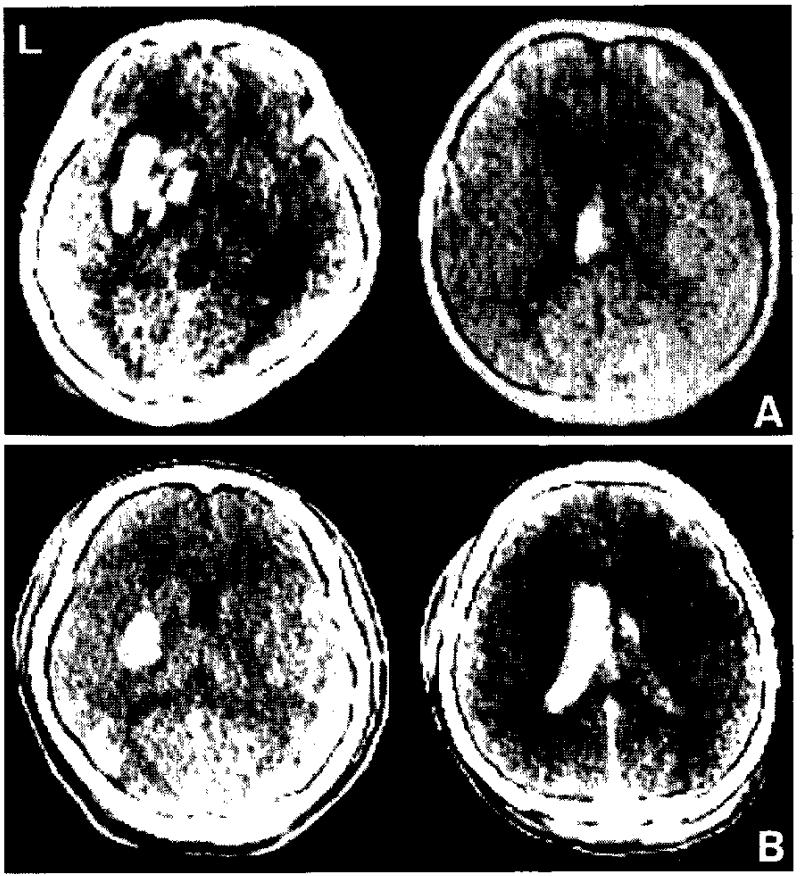

Fig. 4 Representative CT scans of the central hematoma group, showing intracerebral hematomas at the basal ganglia and corpus callosum in children (A) and adults (B).

\section{したものと考光られる。}

次に，本群に和计る小罗上成人の臨床的事項を比較し， 小児の特徽を検討した，性別るみると成人、小児とるに男 性が王倒的に多く，小児に拈いても女览に比べて男児に受 傷の機会の多いことを示している，受傷原因をみると，成 人では転倒あるいは転落が半数以上を占め，作業中の事故 が多く，一方小児では歩行中の交通外傷が多かった。 また 骨折の有無をみると，成人では約半数に，小児では大多数 に骨折を認め，いずれも強い外力による受傷を示唆してい た、血腫と外力との関係をみると，成人では contre-coup injuryがやや多い傾向を示していたが，小児では coup injury $と$ contre-coup injury が同数であった。

受傷より血腫形成までの時間をみると，I群すなわら初 回 CTですでに血腫の形成を認めた群の成人では，10日目 に来院した 1 例索除いた10例を多ると，4時間以内が 6 例， $9 \sim 10$ 時間が 2 例, $20 \sim 24$ 時間が 2 例で, 大半は受傷啳 4 時間以内に，最短 2 時間ですでに血腫の形成をみている.

一方小児では，全例 5 時間以内，5ら4例は 3 時間以内て あり，成人と同様きわめて早期に血腫の形成をみている.

また，II群すなわち初回 CTにて明らかな挫傷を認めた群 の挫傷より血腫形成までの時間は，成人では大半が48時間 以内，小児の 1 例は48時間であったが，これらはより頻回 にCTが施行されたならば，より早期に血腫形成が認めら れたものとも考えられた。すなわち，I－II群でみると， 
成人および小児ともにきわめて早期に，大半は受傷後24時 間以内に血腫汧成されることを示して抏り，こ机は他の 報告2)とも一致するものである。しかし，初回 CTで明ら かな挫傷を認めず isodensityを示した正群では, 初回 CT より血腫形成までの時間が成人で24時間であるのに対し て，小児では 3〜5 日と明らかに成人に比較して長く小児 の特徵とも考えられ，小児では臨床症状を観察しながら受 傷後数日間はCT 行らことが必要であることを示してい る.

血腫の部位とその形態をみると，成人では他の報 告3,8,17) 上同样，多〈は前頭葉あるいは側頭葉に血腫が存 在し，しかも全例強い挫賃を伴った比較的大きな血腫で, 21例中18例 (85.7\%)に手術が行われた。一方小児では，前 頭葉や側頭葉の注かに，頭頂葉また成人にはみら扎なか。 太後頭葉や小脳にもみられ，乙かも血腫の多くは小さく挫 傷もきわめて軽改で，手術を要したものは 9 例中 2 例 (22.2\%)のみであり，成人とは血腫の形態を異にしてい た。

転帰をみると，成人では MD 以上と SD 以下が半々で あるのに対し，小児では死亡1例を除く8例はすべて MD 以上であり，小児の転帰は成人と比較して明らかに 良好であった。

\section{2. 中心白質部血腫群}

脳梁，基底核，傍側脳室に血腫を認め心群で，中心性閉 鎖性脳損傷 ${ }^{18)}$ に属し，CT 出現以前には診断がきわめて困 難であったこのような部位の血腫の報告も近年散見される ようになった，本群の出血の機序に関しては多くの報告が あるが，その主体は Holbourn ${ }^{9}$ の提唱した頭蓋に対寸る 回転性の外力が白質と灭白質の層の間に剪力を生ずる，す なわち shear strainの概念である。脳梁部血腫に関しては 大脳白質 shearing injury の特徵の一つとされ，側頭部に衝 撃が加わると大脳内に複雑な剪力が発生し，脳梁にも矢状 方向や上下方向の剪力が加わるために前大脳動脈が偏位 し，この呀通枝である short callosal arteryが牽引され neurovascular friction が発生して出血すると考光られてい $3^{199}$ 。をた基底核部血腫は，基底核部には白質と密度の異 なる基底核が混在しており shear strainが働きやすく ${ }^{16)}$, この部に分布寸る前脈絡叢動脈 15 名含多数の穿通枝や小 血管のあるものを損傷して出血をきたすとされている，傍 側脳室部血腫は, 外傷性脳室内出血の際に enhancement CTに打いて irregular subependymal enhancement るとの報告もあり23)，こ机は shear strainが脳室壁に加わ り, ependyma たな subependymal structure $の$ 損傷また は血管の損傷をきたしたもの上考えられ，同様の機序に上 傍側脳室に出血するのであるう。このように，本群の血
腫形成機序は，皮質・皮質下血腫群とは異なり， shear strainにより説明されている。

次に本群の成人と小児を比較し，小児の特徽につき検討 した，安ず本群の小児と成人の頻度をみると，小児の $40 \%$

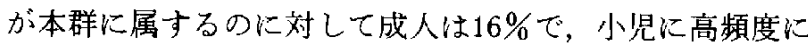
みられた。一方，本群に属する成人の平均年秢は21.5才 で，皮質・皮質下血腫群に比較する之明らかに若年層成人 に多くみられ，また臨床像に関しても小児と成人で多くの 共通点がみられた。すず受傷原因では，小坚および成人と るに全例が交通外傷で強力な外力に上る受傷であり，血腫 と外力との関係もほとんどの例で不明であった，入院時の 意識障害も GCS の平均は小児で6.7，成人で 8.5 ととも 高度の意識障害を示しており, 解像力の問題もあり CT上 脳幹損傷の明らかな所見には欠けるが， shear strainが脳 幹にも及んだ可能性を示していた。 また，小児拉よび成人 ともに受傷上り初回 CT までの時間は全例 3 時間以内で, 两者ともに血腫は比較的小さく，李た挫傷も強くなく，以 後の CT でも血腫の增大は認められず，基底核部血腫にお いても手術適応のあったものは小览の1例のみであっだ。 転带をみると，成人の多くがSD以下であるのに対して， 小児では多くがMD以上であり，成人上比較して小児が やや良好な結果を示して扣り，小児損傷脳の回復性の良さ を示していた，このよらに，本群は小児扣上び若年層成人 に多くみられ，主た臨床像も共通する点が多く，両者に特 徵的なものかも知れない，最近本群婂属する報告例もいく

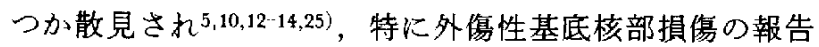
は增えつつあり，さらに小児例のまとまった報告1,16,20) あるが，これらの報告でも特に小児例の頻度には言及して いない。しかしこれらの報告でも，成人と比較して小児で は脳がより回転しやすい㑯向にあり, shear strainを生じ やすいとしており ${ }^{20)}$ ，本報告の傾向を裹付故るものとも考 えられる。

\section{V 結 語}

小児外傷性脳内血腫15例を皮質 - 皮質下血腫群と中心白 質部血腫群に分類し，成人 25 例孝対照群としてその臨床的 特徽を検討した。

1. 皮質・皮質下血腫群

(1) 小児怙上び成人ともに男性に多く，主たる受傷原 因は成人が転倒または転落であるのに対して小児で は交通外傷であり，多くの症例で頭蓋骨骨折を認め た，外傷の種類は coup, contre-coup injuryが活活 同数であった。

(2) 成人・小児ともに受傷後早期に，多くは24時間以 内飞血腫の形成をみた。しかし, 初回 CTで 
isodensityを示した小児例では，成人と比較して血 腫形成まで長時間を要した。

(3)成人では血腫の多くは前頭葉あるいは側頭葉にみ られたが，小児では前頭葉や側頭葉のほかに頭頂 葉・後頭葉・小脳に车欢らた。

(4)小児では成人に比して血腫は小さく，挫傷むきわ めて軽政であり，手術を要した症例は成人 $85.7 \%$ に 対し小児では22.2\%であった。

(5)小巟例の転㷌は，成人上比較して明らかに良好で 苏った。

2. 中心白質部血腫群は，小児和よび若年層成人に多く みられ，臨休的特改は小昌と成人に共通する点が多か った.

（1) 受傷原因はすべて交通外傷で，強力な外力による 受傷であった。

(2) 初骖時の意識障害は高度であったが，血腫は比較 的小さく，手術適応のあったものは小児基底核部血 腫の1例のみであった。

(3)転帰は成人に比して小児がやや良好であった。

本論文の要旨は，第 8 回外傷研究会 (1985年 2 月，東京)，打上 び第44回日本脳神経外科学会総会(1985年10月，長崎)に沶いて発 表した。

\section{文献}

1) 秋本宏, 牧豊, 蓮江正道, 田島賢一, 白井鎮夫, 上 佐統一：小児に扣ける外傷性基底核部損傷。小児の脳神 4: $215-224,1979$

2）有賀 徹, 益澤秀明, 青柳訓夫, 三井香児，間中信也：外 㑺珄脳内血腫の生成一定量的脳損傷作製法による検討一. 神 経外傷 1: 153-159, 1978

3）有賀 徹，益澤秀明，水谷弘，三井香児，江口恒良，任 野圭司：外傷性脳内血腫の生成一CT 上遷趧型発生を示した 症例加 5一. Neurol Med Chir (Tokyo) 19: 459-466, 1979

4) Courvill CB: Traumatic intracerebral hemorrhages with special reference to the mechanics of their production. Bull Los Angeles Neurol Soc 27: 22-38, 1962

5) Dublin $A B$, French BN, Rennick JM: Computed tomography in head trauma. Radiology 122: 365-369, 1977

6) Evans JP, Scheinker IM: Histological studies of the brain following head trauma. I: Post-traumatic cerebral swelling and edema. J Neurosurg 2: 306-314, 1945

7) Evans JP, Scheinker IM: Histological studies of the brain following head trauma. II: Post-traumatic petechial and massive intracerebral hemorrhage. $J$ Neurosurg 3: 101-113, 1946

8）深町 彰, 河野和幸, 若尾哲大, 田崎 健，小泉英仁，永
関慶重：外傷性脳内血腫一経時的 CT 娭査所見に基ついた分 類について一. Neurol Med Chir (Tokyo) 19: 1039-1051, 1979

9) Holbourn AHS: The mechanics of brain injuries. Br Med Bull 3: $147-159,1978$

10）本藤秀樹, 吉嶋淳生, 日下和昌, 松本圭蔵：外傷性大脳基 底核部出血の2 例，神経外傷 1:101-105, 1978

11) Jennett B, Bond M: Assessment of outcome after severe brain damage: Practical scale. Lancet 1: 480-484, 1975

12）小林士郎：外傷性一次性脳幹部損傷のCTによ万分類と予 後について. Neurol Med Chir (Tokyo) 22:838-848, 1982

13）小林土郎，中沢省三，有賀徹，矢埜正実，大塚敏文，西 岜信男，本多一義：外傷性脳幹部損傷 - C C T scan 上 high densityを呈した症例より一。脳神外科 8: 1165-1174，1980

14) Lanksch $W$, Meese $W$, Kazner E: CT findings in closed head injuries with special reference to contusions, in Lanksch W, Kazner E (eds): Cranial Computerized Tomography. Berlin, Springer, 1976, pp 318-328

15) Mosberg $W H$, Lindenberg R: Traumatic hemorrhage from anterior choroidal artery. $J$ Neurosurg 16: 209-221, 1959

16）宗本 滋，駒井杜詩夫，四十住伸一，木村 明，石黑修三， 山本信二郎：小児外傷性大脳基底核部出血 05 例。脳神外科 13: 1027-1033，1985

17）永関慶重，田村 勝，堀越悟：外傷性脑内血腫の形成機 序一超急性期上り追跡しえた CT 所見の解析一. Neurol Med Chir (Tokyo) 24: 316-323, 1984

18）中村紀夫：脸外傷の病理と臨床応用. Neurol Med Chir (Tokyo) 19: 853-862, 1979

19) 中村紀夫：頭部外傷，急性期のメカ二ズムと詏断. 東京. 文光堂, $1986,789 \mathrm{pp}$

20）中村芳澍, 戸谷重雄, 大谷光弘, 大平貴之, 村上秀樹, 宫 崎㕕道, 平井秀幸, 村瀬活郎：外傷性基底核部損傷の小児例 の検討。神経外傷 8: 65-71, 1985

21) Scheinker IM: Vasoparalysis of the central nervous system. A characteristic vascular syndrome. Arch Neurol Psychiat 52: 43-56, 1944

22) Teasdale G, Jennett B: Assessment and prognosis of coma after head injury. Acta Neurochir (Wien) 34: 45.55, 1976

23) Tsai FY, Huprich JE: Further experience with contrastenhanced CT in head trauma. Neuroradiology 16:314-317, 1978

24）坪川孝志, 山田実絃, 富沢憲民, 後藤利和, 篠崎秀雄, 森 安信雄：外傷性脳内血腫の血腫形成機序上りみた分類. Neurol Med Chir (Tokyo) 19: 1127-1137, 1979

25) Zimmerman RA, Bilaniuk LT: Computed tomography of shearing injuries of the cerebral white matter. Radiology 127: 393-396, 1978

〔別刷請求先：干143 東京都大田区大森西6-11-1, 東邦大学脳 神経外科，松元幹郎] 